\title{
ANALISIS TERHADAP HAK PILIH TNI DAN POLRI DALAM PEMILIHAN UMUM*
}

\author{
Setiajeng Kadarsih dan Tedi Sudrajat \\ Fakultas Hukum Universitas J enderal Soedirman Purwokerto \\ E-mail: Setiajeng.kadarsih@unsoed.ac.id dan t_sudrajat@yahoo.com
}

\begin{abstract}
In this reformation era, there were discourses on the recovery of the right to vote for members of the Indonesian National Army (TNI) and Indonesian National Police (Polri) in the General Election. The willingness of those recovery based on the development of democratization and human rights, that places the right to vote as a fundamental right that cannot be infringed by the state. The problem that arises are how the arrangement of the right to vote for the TNI and Polri in the Indonesian General Election when it viewed from the perspective of the political history and how the legal synchronization between the right to vote for TNI and Polri when it viewed from the conception of human rights in the context of a democratic society in Indonesia. Based on the results, it known that there are setback in the arrangement of the right to vote for armed forces and police in three periods. In old order, armed forces and police were given the right to vote in the election. In the new order, the Armed Forces were not entitled to vote, but the presence of armed forces in the realm of regulated political sphere in particular through the lifting mechanism in the legislature. While in reformation era, the right to vote and vote for members of the military and police were removed, so the military and police only carry out the state tasks without any political rights inherent in that institution. This indicates that the legal arrangements concerning the right to vote according to the perspective of human rights in the context of a democratic society is not yet in sync with each other.
\end{abstract}

Key words : Human rights, democratic society and legal synchronization

\begin{abstract}
Abstrak
Pada era reformasi ini, terdapat wacana tentang pemulihan hak pilih bagi anggota Tentara Nasional Indonesia (TNI) dan Kepolisian Negara Republik Indonesia (Polri) pada Pemilihan Umum. Adapun keinginan pemulihan hak tersebut didasarkan pada perkembangan proses demokratisasi dan Hak Asasi Manusia yang menempatkan hak pilih sebagai hak dasar yang tidak dapat disimpangi/dilanggar oleh negara. Permasalahan yang timbul adalah bagaimanakah pengaturan tentang hak pilih bagi TNI dan Polri dalam Pemilihan Umum di Indonesia apabila dilihat dari perspektif sejarah dan politk hukum serta bagaimanakah sinkronisasi hukum terhadap hak pilih bagi TNI dan Polri dengan konsepsi Hak Asasi Manusia dalam konteks masyarakat demokratis di Indonesia. Berdasarkan hasil penelitian dapat diketahui bahwa pengaturan pada tiga periode kekuasaan mengalami kemunduran. Pada masa Orde Lama, angkatan bersenjata dan polisi diberikan hak memilih dalam Pemilu. Pada Orde baru, ABRI tidak diberikan hak untuk memilih, namun keberadaan ABRI dalam ranah ranah politik diatur secara khusus melalui mekanisme pengangkatan dalam lembaga legislatif. Sedangkan pada era reformasi, hak pilih dan memilih bagi anggota TNI dan Polri dihilangkan sehingga TNI dan Polri hanya melaksanakan tugas negara tanpa adanya hak politik yang melekat dalam diri instansi tersebut. Hal tersebut mengindikasikan bahwa pengaturan hukum tentang hak pilih menurut perspektif Hak Asasi Manusia dalam konteks masyarakat demokratis belumlah sinkron satu dengan lainnya. Hal ini dikarenakan kriteria partisipasi dan keterwakilan sebagaimana termaktub dalam nilai-nilai ideal demokrasi belumlah terwujud.
\end{abstract}

Kata kunci : Hak asasi manusia, masyarakat demokratis dan sinkronisasi hukum 


\section{Pendahuluan}

Membicarakan masalah hak asasi dalam perkembangan masyarakat demokratis, maka ini memiliki korelasi yang erat dengan kebutuhan dan keinginan manusia untuk berinteraksi dengan sesama guna menunjukan eksistensi dan upaya pencapaian tujuan. Hak asasi tersebut kemudian menjelma tatkala Tuhan Yang Maha Esa menciptakan seperangkat hak yang menjamin derajatnya sebagai manusia. Hak-hak inilah yang kemudian disebut dengan Hak Asasi Manusia (HAM). Secara normatif, HAM didefinisikan sebagai seperangkat hak yang melekat pada hakikat dan keberadaan setiap manusia sebagai makhluk Tuhan Yang Maha Esa dan merupakan anugerah-Nya yang wajib dihormati, dijunjung tinggi, dan dilindungi oleh Negara, Hukum, Pemerintahan, dan setiap orang, demi kehormatan serta perlindungan harkat dan martabat manusia (Pasal 1 angka 1 UU No. 39 Tahun 1999 tentang Hak Asasi Manusia, dan UU No. 26 Tahun 2000 tentang Pengadilan Hak Asasi Manusia). Hal ini berarti bahwa yang dimaksud sebagai HAM adalah hak yang melekat pada diri setiap pribadi manusia dan oleh karena itu setiap manusia diciptakan kedudukannya sederajat dengan hak-hak yang sama sehingga prinsip persamaan dan kesederajatan telah menjadi hal utama dalam interaksi sosial. ${ }^{1}$

HAM selalu terkait dengan sistem politik demokrasi dalam suatu negara. Demokrasi merupakan sarana guna terciptanya peran serta politik masyarakat secara luas dengan instrumen pokoknya adalah partai politik (parpol). Dalam kaitan ini, peran serta masyarakat menjadi satu kunci dalam mengidentifikasi kualitas kiprah dari lembaga-lembaga sosial politik yang hidup di masyarakat. Dengan meluasnya gagasan bahwa rakyat harus diikutsertakan dalam proses politik, maka parpol lahir dan berkembang menjadi penghubung penting antara rakyat dan pemerintah, bahkan parpol dianggap sebagai perwujudan atau lambang negara modern. Hal ini bermakna bahwa peran serta

Hesti Armiwulan, "Hak Asasi Manusia dan Hukum", Jurnal Yustika, Vol. 7 No. 2, Desember 2004, Surabaya: Fakultas Hukum Universitas Surabaya, hlm. 313. merupakan persoalan relasi kekuasaan atau relasi ekonomi-politik antara negara (state) dan masyarakat (society). Negara adalah pusat kekuasaan, kewenangan dan kebijakan untuk mengatur (mengelola) alokasi barang-barang (sumberdaya) publik pada masyarakat, sedangkan di dalam masyarakat sendiri terdapat hak sipil dan politik, kekuatan massa, kebutuhan hidup, dan lain-lain. Dengan demikian, peran serta dijadikan sebagai jembatan penghubung antara negara dan masyarakat agar dapat menyelenggarakan pemerintahan yang demokratis dan membuahkan kesejahteraan serta human well being.

Mencermati perjalanannya, konsep demokrasi kemudian memberikan gambaran tentang peran serta sebagai unsur yang sangat dibutuhkan untuk membangun pemerintahan yang bertanggungjawab (accountability), transparan (transparency), dan responsif (responsibility) terhadap kebutuhan masyarakat. Tiadanya peran serta masyarakat akan membuahkan pemerintahan yang otoriter dan korup. Dari sisi masyarakat, peran serta dimaksudkan sebagai kunci pemberdayaan (empowerment). Peran serta memberikan ruang dan kapasitas bagi masyarakat untuk memenuhi kebutuhan dan hak-haknya, mengembangkan potensi dan prakarsa lokal, mengaktifkan peran masyarakat serta membangun kemandirian masyarakat. Hal ini berarti bahwa keberadaan dari peran serta merupakan penjabaran dari demokrasi yang bertautan dengan nomokrasi yang terjelma dalam bentuk hak politik.

Berdasarkan hal di atas, maka demokrasi dilihat dari bentuknya telah diwarnai oleh pandangan hidup/ideologi bangsa, di mana substansinya adalah sama yaitu menunjukan adanya peran serta/partisipasi aktif rakyat di dalam pemerintahan yang dilandasi persamaan dan kemerdekaan/ kebebasan. Partisipasi aktif atau partisipasi politik merupakan ukuran tentang betapa pentingnya kedudukan dan hubungan individu dalam negara. Hal tersebut bermakna bahwa pengakuan kebebasan dalam sistem politik merupakan konsekuensi logis atas hak-hak sipil dan politik sebagaimana termaktub dalam konsepsi hak asasi manusia me- 
Ialui kehidupan kenegaraan dan kegiatan pemerintahan. Hak-hak sipil dan politik adalah hak yang bersumber dari martabat dan melekat pada setiap manusia yang dijamin dan di hormati keberadaannya oleh negara agar manusia bebas menikmati hak-hak dan kebebasannya dalam bidang sipil dan politik. Adapun yang berkewajiban untuk melindungi hak-hak sipil dan politik warga negara adalah pemerintah sesuai dengan Pasal 8 Undang-undang No. 39 tahun 1999 tentang HAM yang menegaskan bahwa perlindungan, pemajuan, penegakan dan pemenuhan HAM terutama menjadi tanggung jawab pemerintah. ${ }^{2}$

Bentuk implementasi dari pemenuhan HAM menurut perspektif politik adalah kebebasan untuk berserikat, berkumpul dan mengeluarkan pikiran. ${ }^{3}$ Hak tersebut merupakan indikator bahwa suatu negara telah melaksanakan demokrasi. Setiap negara yang mengaku sebagai negara hukum yang demokratis harus memasukan aspek peran serta aktif rakyat di dalam konstitusinya yang dilandasi persamaan dan kemerdekaan/kebebasan. Berdasarkan hal tersebut, maka setiap warga negara dijamin oleh konstitusi untuk dapat berperan serta aktif dalam proses politik sebagai sarana untuk mencapai tujuannya dalam rangka merealisasikan kebebasan berserikat, berkumpul dan mengeluarkan pikiran bagi warganegara dalam kehidupan kenegaraan. Di Indonesia, jaminan warganegara terhadap kebebasan berserikat, berkumpul dan mengeluarkan pikiran diatur pasal 28E UUD Negara Republik Indonesia Tahun 1945 yang menyatakan bahwa setiap orang berhak atas kebebasan berserikat, ber-

\footnotetext{
Syamsiar J ulia, "Pelanggaran HAM dan Peranan Polri DaIam Penegakan Hukum di Indonesia", Jurnal Equality Vol. 11 No. 2, Agustus 2006, Medan: Fakultas Hukum Universitas Sumatera Utara, hlm. 116.

3 Hak-hak yang diakui sebagai Hak-Hak Sipil dan Politik sebagaimana dilansir di Departemen Hukum dan HAM Republik Indonesia adalah 1. Hak hidup; 2. Hak bebas dari penyiksaan dan perlakuan tidak manusiawi; 3. Hak bebas dari perbudakan dan kerja paksa; 4. Hak atas kebebasan dan keamanan pribadi; 5 . Hak atas kebebasan bergerak dan berpindah; 6 . Hak atas pengakuan dan perlakuan yang sama dihadapan hukum; 7. Hak untuk bebas berfikir, berkeyakinan dan beragama; 8. Hak untuk bebas berpendapat dan berekspresi; 9. Hak untuk berkumpul dan berserikat; 10. Hak untuk turut serta dalam pemerintahan.
}

kumpul dan mengeluarkan pikiran. Sedangkan jaminan yang sifatnya diakui secara Internasional diatur dalam ketentuan article 20, Declaration of Human Right. Di dalam ketentuan pasal ini dinyatakan bahwa:

"everyone has the right to freedom of peacefull assembly and asociation and no one may be compilled to belong an association".

Analog isi pasal tersebut adalah pertama, setiap orang mempunyai hak atas kebebasan berkumpul dan berpendapat; dan kedua, Tiada seorang juapun dapat dipaksa memasuki salah satu perkumpulan. Kebebasan seperti diuraikan dalam article 20 tersebut bersifat universal namun yang tidak universal adalah implementasinya dalam produk perundang-undangan. Hal inilah yang kemudian menimbulkan pertanyaan bagi Pegawai negeri, ${ }^{4}$ khususnya Tentara Nasional Indonesia (TNI) dan Kepolisian Negara Republik Indonesia (Polri) terhadap hak politik berupa hak pilih yang seharusnya melekat dalam statusnya.

Pada awalnya, wacana tentang hak pilih TNI disampaikan oleh mantan Panglima TNI J enderal Endriartono Sutarto agar anggota TNI menggunakan hak pilinnya, karena dalam Pemilu 2004 TNI dan Polri tidak berhak menggunakan hak pilihnya. ${ }^{5}$ Saat ini, terdapat 2 (dua) kelompok yang saling memberikan argumentasinya. Kelompok pro adalah aktivis prodemokrasi dan HAM yang menilai bahwa hak politik perorangan merupakan hak asasi manusia yang harus diberikan kepada siapa pun, termasuk anggota militer. Kedua, kelompok politikus yang menilai dari sisi idealisme demokrasi dan TNI sudah cukup dewasa untuk melakukannya. Sedangkan mereka yang belum setuju pada umumnya datang dari kelompok profesional

Mengenai jenis pegawai negeri didasarkan pada Pasal 2 ayat (1) UU No. 43 Tahun 1999 tentang Pokok-Pokok Kepegawaian yang menyatakan bahwa Pegawai Negeri dibagi menjadi Pegawai Negeri Sipil, Anggota Tentara Nasional Indonesia, dan Anggota Kepolisian Negara Republik Indonesia.

5 Hal tersebut dituangkan dalam Ketetapan Majelis Permusyawaratan Rakyat (Tap MPR) Nomor VII/MPR/ 2000 tentang Pemisahan TNI dan Polri dan juga ditegaskan kembali dalam Undang-Undang (UU) Nomor 12 Tahun 2003 tentang Pemilu. 
yang mengedepankan realisme. Kelompok kontra memandang realitas kondisi sosial-ekonomi yang belum memadai dan kultur politik (terutama elite) yang belum baik, harus dipertimbangkan. ${ }^{6}$

\section{Permasalahan}

Ada dua permasalahan yang hendak di bahas pada artikel ini. Pertama, bagaimanakah pengaturan tentang hak pilih bagi TNI dan Polri dalam Pemilihan Umum di Indonesia?; dan keduan, bagaimanakah sinkronisasi hukum terhadap hak pilih bagi TNI dan Polri dengan konsepsi Hak Asasi Manusia dalam konteks masyarakat demokratis di Indonesia?

\section{Metode Penelitian}

Penelitian ini merupakan penelitian normatif dengan menggunakan beberapa pendekatan masalah yang meliputi pendekatan Undang-Undang (statute approach), pendekatan konseptual (conceptual approach) dan pendekatan sejarah (historical approach). Dalam menganalisis permasalahan pertama digunakan penelitian terhadap asas-asas hukum. Dalam tingkatan ini dilakukan penelitian terhadap kaidah-kaidah hukum yang merupakan patokan bersikap dan berperilaku bagi manusia. Kemudian pada tingkatan kedua, penelitian ini difokuskan pada sinkronisasi hukum, baik secara vertikal mampun horizontal yang bertujuan untuk mengungkapkan kenyataan, sampai sejauh mana perundang-undangan tertentu serasi secara vertikal dan horizontal. Hak pilih TNI dan Polri dalam Pemilu kemudian di korelasikan dengan materi muatan dalam hukum administrasi dan hak asasi manusia untuk mengetahui pasangan nilai serta kesesuaian makna dalam pengaturannya.

Metode metode analisis yang digunakan adalah normatif kualitatif. Metode analisis tersebut dilakukan dengan cara menginterpretasikan dan mendiskusikan bahan hasil penelitian berdasarkan pada asas-asas hukum, teori-teori

\footnotetext{
- Departemen Pertahanan dan Keamanan, 24 J uni 2010, Hak Pilih TNI, Bagai Pedang Bermata Dua, dapat diakses dalam http:// www.dephan.go.id/ modules. php?name= News\&file $=$ article $\&$ sid $=7514$
}

hukum, pengertian hukum, norma hukum, serta konsep yang berkaitan dengan pokok permasalahan. Analisisnya dilakukan secara deduktif yaitu menarik kesimpulan dari suatu permasalahan yang bersifat umum terhadap permasalahan yang dihadapi. Dalam menganalisis bahan hukum berupa peraturan perundang-undangan digunakan beberapa jenis interpretasi yang meliputi interpretasi gramatikal, interpretasi sistematis dan interpretasi menurut penetapan suatu ketentuan perundang-undangan (wet historische-interpretatie).

\section{Pembahasan \\ Pengaturan tentang hak pilih bagi TNI dan Polri dalam Pemilihan Umum di Indonesia}

Pengaturan tentang hak pilih Tentara Nasional Indonesia (TNI) dan Kepolisian Republik Indonesia (Polri) pada dasarnya dipengaruhi oleh perkembangan demokratisasi di Indonesia dan sejarah hukum dari masing-masing lembaga tersebut. Dalam pembahasan ini, perspektif sejarah digunakan dalam rangka penelaahan sejumlah peristiwa-peristiwa yuridis dari zaman dahulu yang disusun secara kronologis. Dalam hal ini, hukum sebagai gejala sejarah berarti tunduk pada pertumbuhan yang terus menerus. Pengertian tumbuh membuat dua arti yaitu perubahan dan stabilitas. Hukum tumbuh, berarti bahwa terdapat hubungan yang erat, sambung-menyambung atau hubungan yang tak terputus-putus antara hukum pada masa kini dan hukum pada masa lampau. Hukum pada masa kini dan hukum pada masa lampau merupakan satu kesatuan. Ini berarti bahwa kita dapat mengerti hukum kita pada masa kini, hanya dengan penyelidikan sejarah, bahwa mempelajari hukum secara ilmu pengetahuan harus bersifat juga mempelajari sejarah. Dalam kaitan ini, sejarah pengaturan hukum mempunyai arti penting dalam rangka pembinaan hukum nasional, oleh karena usaha pembinaan hukum tidak saja memerlukan bahan-bahan tentang perkembangan hukum masa kini saja, akan tetapi juga bahan-bahan mengenai perkembangan dari masa lampau. Melalui perspektif sejarah, diharapkan mampu menjajaki berbagai aspek politik hukum Indonesia pada 
masa yang lalu, hal mana akan dapat memberikan bantuan untuk memahami kaidahkaidah serta institusi-institusi hukum yang ada dewasa ini dalam masyarakat bangsa kita. ${ }^{7}$

Berdasarkan perspektif tersebut, sifat dan arah hukum mengenai hak pilih TNI dan Polri selalu diwarnai oleh kepentingan politik penguasa. Perjalanan politik bangsa menunjukan kecenderungan yang sangat kuats bahwa militer merupakan instrumen politik yang sangat efektif yang dibangun oleh sebuah rezim guna membesarkan dan mempertahankan kekuasaan yang ada. ${ }^{8} \mathrm{Hal}$ itu sebenarnya bukanlah sesuatu yang baru, karena pola-pola pemanfaatan militer sebagai instrumen politik rezim terjadi sejak pemerintahan kolonial. Untuk memperjelas perjalanan demokrasi dalam perspektif sejarah dan politik hukum terkait dengan hak pilih angkatan bersenjata (TNI) dan Polri dapat dicermati dengan penelaahan terhadap 3 (tiga) periode kekuasaan di Indonesia yang meliputi Orde Lama, Orde baru dan reformasi.

\section{Pengaturan hak Pilih Angkatan Bersenjata dan Polri pada masa Orde Lama}

Momentum historis perkembangan demokrasi setelah kemerdekaan ditandai dengan keluarnya Maklumat No. X pada 3 November 1945 yang ditandatangani oleh Muhammad Hatta. Dalam maklumat tersebut dinyatakan bahwa perlunya berdirinya partai-partai politik sebagai bagian dari demokrasi, serta rencana pemerintah menyelenggarakan pemilu pada J anuari 1946. Maklumat Muhammad Hatta berdampak sangat luas, melegitimasi partai-partai politik yang telah terbentuk sebelumnya dan mendorong terus lahirnya partai-partai politik baru. Pada tahun 1953, Kabinet Wilopo berhasil menyelesaikan regulasi pemilu dengan ditetapkannya Undang-Undang No. 7 tahun 1953 tentang Pemilihan Anggota Konstituante dan Ang-

Lihat dan bandingkan dengan Hasnati, "Pertautan Kekuasaan Politik dan Negara Hukum", J urnal Hukum Respublica, Vol. 3 No. 1, Tahun 2003, Pekanbaru: Fakultas Hukum Universitas Lancang Kuning, hlm. 102-113.

8 Nurhasan, "Pasang Surut Penegakan HAM dan Demokrasi di Indonesia", Jurnal IImu Hukum Litigasi, Vol. 6 No. 2, J uni 2005, Bandung: Fakultas Hukum Universitas Pasundan, hlm. 215. gota Dewan Perwakilan Rakyat. Pemilu multipartai secara nasional disepakati dilaksanakan pada 29 September 1955 (untuk pemilihan parlemen) dan 15 Desember 1955 (untuk pemilihan anggota konstituante). ${ }^{9}$

Mencermati aspek kesejarahannya, Pemilihan Umum Indonesia 1955 adalah pemilihan umum pertama di Indonesia dan diadakan pada tahun 1955. Pemilu ini dapat dikatakan sebagai pemilu Indonesia yang paling demokratis. Bahkan Indonesianis seperti Herbert Feith menilai bahwa Pemilu 1955 adalah yang paling demokratis dibandingkan pemilu sepanjang pemerintahan Orde Baru. Walapun Pemilu 1955 dilaksanakan saat keamanan negara masih kurang kondusif, ${ }^{10}$ namun anggota angkatan bersenjata dan polisi diikutsertakan untuk memilih. Mereka yang bertugas di daerah rawan kemudian diberikan kesempatan untuk datang ke tempat pemilihan dan pada akhirnya Pemilu berlangsung dalam situasi yang aman.

Pengaturan tentang hak memilih bagi anggota angkatan bersenjata dan Polri ditegaskan dalam Undang-Undang No.7 Tahun 1953 tentang Pemilihan Anggota Konstituante dan Anggota Dewan Perwakilan Rakyat. Pada Pasal 1 ayat (1) ditentukan bahwa :

Anggota Konstituante dan anggota Dewan Perwakilan Rakyat dipilih oleh warga negara Indonesia, yang dalam tahun pemilihan berumur genap 18 tahun atau yang sudah kawin lebih dahulu.

Pasal 3 ayat (1) menentukan bahwa

Pemerintah mengadakan ketentuan-ketentuan khusus untuk memungkinkan pelaksanaan hak-pilih bagi anggota-anggota Angkatan Perang dan Polisi, yang pada hari dilakukan pemungutan suara sedang

Pemilu ini bertujuan untuk memilih anggota-anggota DPR dan Konstituante. Jumlah kursi DPR yang diperebutkan berjumlah 260, sedangkan kursi Konstituante berjumlah 520 (dua kali lipat kursi DPR) ditambah 14 wakil golongan minoritas yang diangkat pemerintah. Pemilu ini dipersiapkan di bawah pemerintahan Perdana Menteri Ali Sastroamidjojo. Namun, Ali Sastroamidjojo mengundurkan diri dan pada saat pemungutan suara, kepala pemerintahan telah dipegang oleh Perdana Menter Burhanuddin Harahap.

10 Keadaan ini disebabkan karena beberapa daerah dirundung kekacauan oleh DI/TII (Darul Islam/Tentara Islam Indonesia) khususnya pimpinan Kartosuwiryo. 
dalam menjalankan tugas operasi atau tugas biasa di luar tempat kedudukannya dan apabila perlu dengan mengadakan dalam waktu sependek-pendeknya pemungutan suara susulan untuk mereka itu.

Mencermati hal diatas, maka pada era Orde Lama anggota angkatan bersenjata dan Polri diberikan hak yang sama sebagai warga negara dalam ranah politik. Hal ini dikarenakan pada era revolusi kemerdekaan, angkatan bersenjata dan Polri senantiasa menghadapi permasalahan sosial, politik, dan ekonomi sehingga mereka memiliki kedewasaan dalam pelaksanaan tugasnya dan tidak memiliki tendensi kekuasaan. Perlu dicermati bahwa walau mereka memilih beragam partai, namun institusi angkatan bersenjata dan Polri tetap utuh. Adapun mengenai politisasi angkatan bersenjata dan Polri tidaklah hadir pada saat pemilu, melainkan ketika terjadi persoalan dalam hubungan antara pemerintah pusat dan daerah. ${ }^{11}$.

Hal diatas bermakna bahwa Pemilihan Umum pertama nasional di Indonesia pada 1955 telah mendekati kriteria demokratis, sebab selain jumlah parpol tidak dibatasi, berlangsung dengan langsung umum bebas rahasia (luber), serta mencerminkan pluralisme dan representativeness karena melibatkan seluruh elemen masyarakat, termasuk didalamnya adalah anggota angkatan bersenjata dan kepolisian.

\section{Pengaturan Hak Pilih Angkatan Bersenjata Republik Indonesia (ABRI) pada masa Orde Baru}

Pada masa Orde Baru, lembaga TNI dan Polri dijadikan sebagai alat untuk mempertahankan rezim pemerintahan yang dipimpin oleh Presiden Soeharto yang notabene dari kalangan militer. Untuk mempertahankan kekuasaannya, Presiden Soeharto tidak hanya menjadikan TNI dan Polri sebagai alat pertahanan dan keamanan, tetapi juga menjadikannya sebagai kekuatan sosial, politik, dan

11 Saat itu masih banyak sekali komandan daerah yang yang tidak tunduk pada komando TNI di J akarta. Politisasi semakin kental pada era Demokrasi Terpimpin saat terjadi permasalahan internal antara Presiden Soekarno, TNI AD, dan PKI. ekonomi yang punya akses berlebih untuk mengatur kehidupan berbangsa dan bernegara melalui format dwifungsi ABRI.

Adapun pengaturan pada masa Orde baru yang menegaskan terdapatnya upaya politisasi lembaga militer termaktub dalam Ketetapan No. XXIV/MPRS/ 1966 tentang Kebijaksanaan Dalam Bidang Pertahanan dan Keamanan yang menyatakan bahwa dibentuknya suatu integrasi tiga angkatan dan kepolisian dalam ABRI dan Dephankam. Penegasan terhadap Ketetapan tersebut dituangkan kembali dalam Keputusan Presiden No. 132 tahun 1967 pada tanggal 24 Agustus 1967 tentang pokok-pokok organisasi departemen Hankam yang menyatakan bahwa ABRI terdiri atas tiga angkatan dan kepolisian, semuanya di bawah Dephankam.

Adapun mengenai keberadaan ABRI dalam proses politik ditegaskan dalam Undang-Undang No. 15 tahun 1969 tentang Pemilihan Umum Anggota-Anggota Badan Permusyawaratan/ Perwakilan Rakyat. Khususnya Pasal 11 yang menyatakan bahwa Anggota Angkatan Bersenjata Republik Indonesia tidak menggunakan hak memilih serta Pasal 14 yang menyatakan bahwa Anggota Angkatan Bersenjata Republik Indonesia tidak menggunakan hak dipilih.

Dasar dari tidak diberikannya hak pilih dan memilih bagi anggota ABRI dikarenakan

Mengingat dwifungsi $A B R I$ sebagai alat negara dan kekuatan sosial yang harus kompak bersatu dan merupakan kesatuan untuk dapat menjadi pengawal dan pengaman Panca Sila dan Undang-undang Dasar 1945 yang kuat dan sentosa, maka bagi ABRI diadakan ketentuan tersendiri. Fungsi dan tujuan ABRI seperti tersebut di atas tidak akan tercapai jika anggota ABRI ikut serta dalam pemilihan umum, yang berarti bahwa anggota ABRI berkelompok-kelompok, berlain-lainan pilihan dan pendukungnya terhadap golongangolongan dalam masyarakat. Karena itu maka anggota-anggota ABRI tidak menggunakan hak memilih dan hak dipilih, tetapi mempunyai wakil-wakilnya dalam lembaga-lembaga permusyawaratan/ perwakilan rakyat dengan melalui pengangkatan. Duduknya ABRI dalam lembagalembaga permusyawartan/ perwakilan melalui pengangkatan dimungkinkan oleh demokrasi Panca Sila yang menghendaki 
ikut sertanya segala kekuatan dalam masyarakat representatif dalam lembagalembaga tersebut.

Hal diatas menegaskan bahwa memang ABRI tidak diberikan hak untuk memilih dan dipilih, namun didalam wadah ABRI tetap diberikan kewenangan dalam proses politik melalui proses pengangkatan guna menjadi anggota legislatif. Adapun hal tersebut ditegaskan dalam Pasal 10, 14 dan 24 Undang-Undang No. 16 tahun 1969 tentang Susunan dan Kedudukan Majelis Permusyawaratan Rakyat, Dewan Perwakilan Rakyat dan Dewan Perwakilan Rakyat Daerah.

Mencermati pengaturan di atas, maka dalam kurun waktu orde baru, dapat dikatakan bahwa militer turut mendominasi kehidupan sosial-politik nasional dengan menggunakan berbagai justifikasi, seperti konsep dwifungsi ABRI melalui mekanisme pengangkatan dalam lembaga legislatif, bukan melalui pemilihan umum. Hal ini memiliki makna bahwa hak pilih yang melekat pada anggota $A B R I$ mulai digerus dan dipolitisir oleh penguasa. Hal ini kemudian berdampak pada pencitraan negatif dalam diri ABRI karena diberi akses masuk ke dalam lembaga legislatif dan eksekutif melalui mekanisme yang tidak demokratis, serta dianggap menyalahgunakan kekuasaannya untuk kepentingan penguasa.

\section{Pengaturan hak Pilih TNI dan Polri pada Era Reformasi}

Posisi istimewa ABRI dalam kehidupan ber-bangsa dan bernegara berakhir pada tahun 1998, setelah terjadinya gerakan reformasi yang berhasil meruntuhkan rezim yang telah memberinya tempat istimewa yaitu Rezim Orde Baru. Reformasi di tubuh ABRI kemudian memecahkan TNI dan Polri kedalam dua wadah yang berbeda, dengan mengubah paradigma, peran dan fungsi, serta tugas TNI dan Polri.

Ditinjau dari aspek normanya, reformasi TNI dan Polri terkait dengan hak memilih dan dipilih dalam proses politik diawali dengan dikeluarkannya Tap MPR No.Vl/2000 tentang Pemisahan TNI dan Polri serta Tap MPR No.VII/
2000 tentang Peran TNI dan Polri. Adapun peraturan yang mengatur hak pilih anggota TNI tertuang dalam pasal 5 ayat (2) dan (4) Tap MPR No VII/ MPR/ 2000 yang menentukan

TNI bersikap netral dalam kehidupan politik dan tidak melibatkan diri dalam kehidupan politik praktis. Anggota TNI tidak menggunakan hak memilih dan di pilih. Keikutsertaan TNI dalam menentukan arah kebijakan nasional disalurkan melalui MPR paling lama sampai dengan tahun 2009.

Peraturan yang mengatur hak pilih anggota Polri tertuang dalam pasal 10 ayat (1) dan (2) Tap MPR No VII/ MPR/ 2000 yang menentukan Polri bersikap netral dalam kehidupan politik dan tidak melibatkan diri dalam kehidupan politik praktis. anggota Polri tidak menggunakan hak memilih dan dipilih. Keikutsertaan Polri dalam menentukan arah kebijakan nasional disalurkan melalui MPR paling lama sampai dengan tahun 2009.

Peraturan-peraturan tersebut pada prinsipnya bertujuan agar tercipta sikap profesional dari kedua institusi ini dalam menjalankan tugas dan wewenangnya. Hal ini senada dengan pernyataan Prof Dr. B.J Habibie dalam Rapat Paripurna Sidang Umum ke-8 MPR-RI tanggal 14 Oktober 1999 yang menyatakan bahwa bahwa

Untuk menghilangkan campur tangan pemerintah dalam proses pemilu, pemerintah mengatur tentang netralitas POLRI, TNI serta PNS. Demikian juga dalam hal pelaksanaan dan pengawasan pemilu, pemerintah menyerahkan sebagian besar wewenangnya kepada partai politik peserta pemilu, sedangkan pemerintah lebih menempatkan diri sebagai fasilitator.... selain dari itu, dalam rangka menghapuskan KKN dikalangan PNS, maka dedikasi dan profesionalisme pegawai negri sipil perlu ditingkatkan, seiring dengan perbaikan imbalan yang mereka terima. Kita menginginkan birokrasi yang bersih, netral dan profesional. Pengaturan tentang PNS tidak boleh menjadi anggota dan pengurus partai politik $d$ maksudkan untuk menjaga netralitas tersebut. Dengan demikian, PNS dapat memberikan pelayanan kepada masyarakat secara profesional, optimal, adil dan mera- 
ta tanpa mempertimbangkan golongan maupun aliran politik yang ada. ${ }^{12}$

Mencermati konsepsi tentang netralitas politik di atas, maka pemerintah kemudian melakukan perubahan mendasar terhadap hak pilih dari kepolisian Tentara Nasional Indonesia sebagaimana di atur dalam Pasal 28 UndangUndang No.2 tahun 2002 tentang Kepolisian Republik Indonesia dan Pasal 39 Undang-Undang No.34 tahun 2004 tentang Tentara Nasional Indonesia.

Melihat sejarah dari pengaturan bagi TNI dan Polri di bidang perpolitikan, maka terdapat makna bahwa pemerintah telah menghilangkan hak dasar berupa hak memilih dan dipilih bagi anggota TNI dan Polri guna menciptakan situasi yang diinginkan oleh negara. Namun apabila dalam perkembangan demokratisasi di Indonesia, maka pengaturan pada era reformasi mengalami kemunduran yang signifikan karena pada masa Orde Lama, angkatan bersenjata dan polisi diberikan hak memilih sebagaimana termaktub dalam Undang-Undang No. 7 Tahun 1953. Pada Orde baru, ABRI tidak diberikan hak untuk memilih, namun keberadaan ABRI dalam ranah ranah politik diatur secara khusus melalui mekanisme pengangkatan dalam lembaga legislatif. Sedangkan pada era reformasi, hak pilih dan memilih bagi anggota TNI dan Polri di hilangkan sehingga TNI dan Polri hanya melaksanakan tugas negara tanpa adanya hak politik yang melekat dalam diri instansi tersebut.

\section{Sinkronisasi hukum terhadap hak pilih bagi TNI dan Polri dengan konsepsi Hak Asasi Ma- nusia dalam konteks masyarakat demokratis di Indonesia}

Pengaturan tentang hak pilih dalam perspektif pemerintah, pada hakikatnya merupakan upaya untuk memperoleh kepastian hukum guna membatasi kekuasaan terhadap kemungkinan bergeraknya kekuasaan atas nalurinya sendiri, yang pada akhirnya mengarah pada penyalahgunaan kekuasaan (abuse of power). Konsep pembatasan dalam konteks negara hu-

12 Risalah Rapat Paripurna Sidang Umum ke-8 MPR-RI tanggal 14 Oktober 1999 kum pada awalnya dikemukakan oleh Plato melalui konsepsi nomoi yaitu suatu negara di mana semua orang tunduk kepada hukum, termasuk juga penguasa atau raja untuk mencegah agar mereka tidak bertindak secara sewenangwenang. Gagasan bahwa kekuasaan harus di batasi dikemukakan juga oleh Lord Acton yang mengingatkan bahwa pemerintahan selalu di selenggarakan oleh manusia dan bahwa pada manusia itu tanpa kecuali melekat banyak kelemahan. Dalilnya yang kemudian menjadi termasyur adalah "manusia yang mempunyai kekuasaan cenderung untuk menyalahgunakan kekuasaan itu, tetapi manusia yang mempunyai kekuasaan tak terbatas pasti akan menyalahgunakan secara tak terbatas pula (Power tends to corrupt, but absolute power corrupt absolutely)."

Berdasarkan hal di atas, maka pembatasan kekuasaan memiliki korelasi yang erat dengan upaya membatasi perilaku dari penguasa, dan untuk dapat menegaskan aspek kepastian hukumnya, maka didalam setiap peraturan memiliki pembatasan terhadap keberlakuannya. Artinya tidak ada satupun peraturan yang keberlakuannya sepanjang zaman dan memenuhi kebutuhan realitas sosial yang terus berubah, sehingga setiap perubahan pada hakikatnya merupakan konsekuansi logis bagi setiap keinginan untuk memenuhi tuntutan zaman. Terkait dengan pembatasan tersebut, maka di dalam hubungan hukum antara negara dengan pegawai negeri (TNI dan Polri) terdapat ketentuan pembatasan perilaku bagi pegawai yang bekerja dalam instansi negeri. Hubungan ini disebut dengan hubungan dinas publik yang menurut Logemann, hubungan ini terjadi bilamana seseorang mengikatkan dirinya untuk tunduk pada suatu perintah dari pemerintah untuk melakukan sesuatu atau beberapa macam jabatan negeri yang dalam melakukan suatu atau beberapa macam jabatan itu di hargai dengan pemberian gaji dan beberapa keuntungan lain. Hal ini berarti bahwa inti dari hubungan dinas publik adalah kewajiban bagi pegawai yang bersangkutan untuk tunduk pada pengangkatan dalam beberapa macam jabatan tertentu yang berakibat bahwa pegawai yang bersang- 
kutan tidak menolak (menerima tanpa syarat) pengangkatannya dalam satu jabatan yang telah ditentukan oleh pemerintah di mana sebaliknya pemerintah berhak mengangkat seseorang pegawai dalam jabatan tertentu tanpa harus adanya penyesuaian kehendak dari yang bersangkutan. ${ }^{13}$

Hubungan dinas publik ini dalam penerapannya berkaitan dengan segi pengangkatan Pegawai Negeri yang dikenal dengan teori Contrac Suigeneris. Teori ini dikemukakan oleh Buys bahwa dalam Contrac Suigeneris mensyaratkan pegawai negeri harus setia dan taat selama menjadi Pegawai Negeri, meskipun dia setiap saat dapat mengundurkan diri. Dari pendapat Buys ini dapat disimpulkan bahwa selama menjadi Pegawai Negeri, mereka tidak dapat melaksanakan hak-hak asasinya secara penuh. Karena itu, apabila Pegawai Negeri akan melaksanakan hak-hak asasinya secara penuh, pemerintah dapat menyatakan yang bersangkutan bukanlah orang yang diperlukan bantuannya oleh pemerintah.

Makna pemberlakuan hubungan dinas publik adalah timbulnya pembatasan terhadap diri Pegawai Negeri melalui peraturan yang dikenakan kepadanya, termasuk didalamnya adalah hak-hak yang bersifat asasi. Dalam kaitan ini, walaupun hak asasi manusia diakui sebagai hak yang pada dasarnya tak dapat di kurangi, dirampas sedikitpun oleh siapapun, namun demikian hak asasi manusia bukanlah sesuatu yang bisa dinikmati tanpa batas. Terdapat adagium dalam hukum bahwa penikmatan hak seseorang dibatasi yakni oleh penikmatan hak orang lain. Hal ini memiliki makna bahwa suatu perbuatan (penikmatan hak) tidak menimbulkan kerugian pada orang lain, maka tidak ada legitimasi bagi negara untuk merepresi suatu penikmatan hak. ${ }^{14}$ Sebaliknya jika memang penikmatan hak akan mengganggu orang lain, maka pembatasan terhadapnya di

13 Tedi Sudrajat, "Problematika Penegakan Hukuman Disiplin Kepegawaian", J urnal Dinamika Hukum, Vol. 8 No. 3, September 2008, Purwokerto: Fakultas Hukum Universitas J enderal Soedirman, hlm. 214.

14 Lihat dan bandingkan dengan M. Nur Hasan, "Tantangan Demokrasi di Indonesia", Jurnal Aspirasi Vol. 16 No. 1, Juli 2006, Jakarta: Magister IImu Hukum Trisakti, hlm. 33- 40 . mungkinkan terjadi. Akan tetapi, perlu ditegaskan bahwa pembatasan haruslah ditentukan dengan hukum semata-mata untuk tujuan kesejahteraan umum dalam suatu masyarakat yang demokratik. Universal Declaration of Human Right (UDHR) Pasal 29 ayat (2) menentukan bahwa

In the exercise of his rights and freedoms, everyone shall be subject only to such limitations as are determined by law solely for the purpose of securing due recognition and respect for the rights and freedoms of others and of meeting the just requirements of morality, public order and the general welfare in a democratic society.

The International Covenant on Economic, Social and Cultural Rights (ICESCR $)^{15}$ menentukan bahwa hak-hak yang ada di dalam kovenan bisa dibatasi oleh hukum sejauh berkesesuaian dengan sifat dari hak itu dan semata-mata untuk mencapai kesejahteraan umum dalam suatu masyarakat yang demokratik. Pasal 4 ICESCR menentukan bahwa

The States parties to the present Covenant recognize that, in the enjoyment of those rights provided by the State in conformity with the present Covenant, the State may subject such rights only to such limitations as are determined by law only in so far as this may be compatible with the nature of these rights and solely for the purpose of promoting the general welfare in a democratic society.

Sedikit berbeda dengan UDHR dan ICESCR, dalam The International Covenant on Civil and Political Rights (ICCPR) ${ }^{16}$ tidak di jumpai ketentuan pembatasan yang berlaku umum atas setiap pasal di dalam konvensi. ICCPR memungkinkan suatu negara peserta untuk membatasi (to limit) atau menunda (sus-

15 The International Covenant on Economic, Social and Cultural Rights (ICESCR) was adopted by the General Assembly in December 1966 and entered into force in 1976. It elaborates the principles laid out in UDHR and is legally binding on all states who have signed and ratified its provisions.

16 The International Covenant on Civil and Political Rights (ICCPR) was adopted in 1966 elaborates the principles laid out in UDHR and is legally binding on all states who have signed and ratified its provisions. 
pend) penikmatan hak dalam hal secara resmi dinyatakan bahwa negara dalam keadaan darurat yang mengancam kelangsungan hidup suatu bangsa. Pasal 4 ayat (1) ICCPR menentukan bahwa

In time of public emergency which threatens the life of the nation and the existence of which is officially proclaimed, the States Parties to the present Covenant may take measures derogating from their obligations under the present Covenant to the extent strictly required by the exigencies of the situation, provided that such measures are not inconsistent with their other obligations under international law and do not involve discrimination solely on the ground of race, colour, sex, language, religion or social origin.

Sebagaimana ditentukan dalam Pasal 4 di atas, kemungkinan untuk itu (membatasi dan menunda) hanya diijinkan dalam hal sangat diperlukan dalam situasi yang amat genting yang mengancam kehidupan bangsa, serta tak boleh diskriminatif semata pada ras, warna kulit, jenis kelamin, bahasa, agama atau asal sosial.

Pada level perundangan nasional, UUD 1945 hasil amandemen memberikan pembatasan dan kewajiban hak asasi manusia dengan menyatakan: setiap orang wajib menghormati hak asasi manusia orang lain dalam tertib kehidupan bermasyarakat, berbangsa dan bernegara (Pasal 28 J ayat (1) UUD 1945).

Lebih lanjut Pasal $28 \mathrm{~J}$ ayat (2) menentukan

Dalam menjalankan hak dan kebebasannya, setiap orang wajib tunduk kepada pembatasan yang ditetapkan dengan Undang-Undang dengan maksud sematamata untuk menjamin pengakuan serta penghormatan atas hak dan kebebasan orang lain dan untuk memenuhi tuntutan yang adil sesuai dengan pertimbangan moral, nilai-nilai agama, keamanan dan ketertiban umum dalam suatu masyarakat demokratis.

Pembatasan hak asasi manusia dijumpai dalam Piagam Hak Asasi Manusia yang tercantum dalam Ketetapan Majelis Permusya- waratan Rakyat No. XVII/MPR/ 1998 Pasal 34 yang menentukan bahwa setiap orang wajib meng-hormati hak asasi manusia orang lain dalam tertib kehidupan bermasyarakat, berbangsa, bernegara. Piagam Hak Asasi Manusia juga menegaskan bahwa penikmatan hak asasi manusia bisa dibatasi oleh hukum. Ditentukan oleh Pasal 36 dari Ketetapan MPR tersebut bahwa

Di dalam menjalankan hak dan kebebasannya setiap orang wajib tunduk kepada pembatasan-pembatasan yang ditetapkan oleh Undang-Undang dengan maksud semata-mata untuk menjamin pengakuan serta penghormatan atas hak dan kebebasan orang lain, dan untuk memenuhi tuntutan yang adil sesuai dengan pertimbangan moral, keamanan, dan ketertiban umum dalam suatu masyarakat demokratis.

Sementara itu Pasal 70 Undang-Undang No. 39 Tahun 1999 tentang Hak Asasi Manusia juga mengatur limitasi hak asasi manusia dengan menentukan bahwa

Dalam menjalankan hak dan kebebasannya, setiap orang wajib tunduk kepada pembatasan yang ditetapkan UndangUndang dengan maksud untuk menjamin pengakuan serta penghormatan atas hak dan kebebasan orang lain dan untuk memenuhi tuntutan yang adil sesuai dengan pertimbangan moral, keamanan, dan ketertiban umum dalam suatu masyarakat demokratis.

Hal di atas bermakna bahwa pembatasan terhadap hak pilih bagi TNI dan Polri dimaksudkan agar penyelenggaraan tugas pemerintah berupa pertahanan dan keamanan dilaksanakan secara penuh oleh anggota TNI dan Polri. Namun permasalahannya adalah perkembangan masyarakat demokratis di Indonesia semakin mengarah pada konsolidasi politik dalam hal pemberian hak yang sama pada setiap warga negara. ${ }^{17}$

Konsolidasi demokrasi adalah suatu proses pemapanan sistem demokrasi, untuk menuju pada sistem politik yang stabil dan mapan.

\footnotetext{
17 Sumali, "Urgensi TNI di Bingkai Konstitusi Dalam Perspektif Yuridis Politis", J urnal Hukum Respublica, Vol. 3 No. 1, Tahun 2003, Pekanbaru: Fakultas Hukum Universitas Lancang Kuning, hlm. 61.
} 
Konsolidasi demokrasi memerlukan tiga hal, yaitu: pertama, pendalaman demokrasi (democratic deepenning), yakni struktur-struktur politik menjadi semakin terbuka (liberal), akuntabel, representatif dan aksesibel. Ini berarti kebebasan politik dijamin tetapi sekaligus juga tunduk pada hukum; kedua, pelembagaan politik (political institutionalization), yaitu terbangun dan tertatanya struktur-struktur politik dan pemerintahan untuk menjamin terselenggaranya birokrasi yang melayani kebutuhan publik, pemerintahan perwakilan yang mapan dan bertanggungjawab (partai politik, pemilu, badan-badan pemerintahan) yang mencerminkan pluralitas kepentingan masyarakat. Artinya, demokrasi akan dijadikan sebagai model dan aturan main bersama untuk menyelesaikan berbagai persoalan yang dihadapi baik secara sosial, politik, ekonomi dan budaya. Oleh karena itu, salah satu ciri dari konsolidasi demokrasi adalah semakin kuatnya nilai-nilai demokrasi, khususnya jaminan kebebasan untuk berserikat dan berkumpul serta berorganisasi dan tidak adanya tekanan-tekanan politik oleh rezim menjadi salah satu dari sekian indikator. Konsolidasi demokrasi juga dicirikan oleh kuatnya pemahaman elit politik bahwa model demokrasi (sistem demokrasi) adalah pilihan satu-satunya bagi pelaksanaan dan mekanisme untuk melaksanakan pemerintahan. ${ }^{18}$

Mencermati relevansi dari substansi pengaturan tentang pembatasan penikmatan hak asasi manusia karena pertimbangan moral, nilai-nilai agama, keamanan dan ketertiban umum dalam suatu masyarakat demokratis apabila dikaitkan dengan hak pilih bagi anggota TNI dan Polri, maka pengaturan tersebut masih perlu untuk dievaluasi dengan pemikiran bahwa konsep demokrasi tersebut telah mencederai nilai-nilai ideal demokratis dengan adanya penghapusan hak asasi dan dihilangkannya keterwakilan lembaga TNI dan Polri dalam ranah

18 T. Hari Prihatono, 2008, "Departemen Pertahanan-TNIMasyarakat Sipil : Relasi dalam Formulasi Kebijakan dan Transparansi Implementasi," dalam diskusi untuk simposium "10 Tahun Reformasi Sektor Keamanan di Indonesia" dengan tema "Reformasi TNI dan Departemen Pertahanan RI Pasca Orde Baru di Indonesia", yang diselenggarakan atas kerja sama Lesperssi-HRWGIDSPS-DCAF, Hotel Sultan - J akarta 28-29 Mei 2008. politik. ${ }^{19} \mathrm{Hal}$ ini terlihat secara tegas dalam Pasal 5 ayat (2) dan (4) Tap MPR No VII/ MPR/ 2000 yang menentukan bahwa

(2) TNI bersikap netral dalam kehidupan politik dan tidak melibatkan diri dalam kehidupan politik praktis.

(4) Anggota TNI tidak menggunakan hak memilih dan dipilih. Keikutsertaan TNI dalam menentukan arah kebijakan nasional disalurkan melalui MPR paling lama sampai dengan tahun 2009.

Hak pilih anggota Polri diatur dalam pasal 10 ayat (1) dan (2) Tap MPR No VII/ MPR/ 2000 yang menentukan bahwa

Polri bersikap netral dalam kehidupan politik dan tidak melibatkan diri dalam kehidupan politik praktis. anggota Polri tidak menggunakan hak memilih dan di pilih. Keikutsertaan Polri dalam menentukan arah kebijakan nasional disalurkan melalui MPR paling lama sampai dengan tahun 2009.

Nilai-nilai demokratis tersebut dapat di cermati pula melalui konsepsi demokrasi perwakilan yang dikemukakan oleh Henry B. Mayo dalam karyanya yang berjudul "An Introduction to Democratic Theory" yang menegaskan bahwa :

"A Democratic political system is one in which public policies are made on a majority basis, by representatives subject to effective popular control at periodic elections which are conductet on the principle of political equality and under conditions of political freedom" 20

Berdasarkan uraian tersebut, maka dapat dikatakan bahwa unsur keterlibatan atau partisipasi setiap warga masyarakat dalam proses penyelenggaraan pemerintahan adalah sesuatu yang mutlak, terlepas apakah keterlibatan itu secara langsung maupun tidak langsung melalui wakil-wakilnya yang duduk dalam lembagalembaga perwakilan. Kesahan atau legitimasi

19 Lihat dan Bandingkan dengan Albert Hasibuan, "Politik Hak Asasi Manusia (HAM) Dan UUD 1945", Law Review Fakultas Hukum Universitas Pelita Harapan, Vol. 8 No. 1, J uli 2008, hlm. 43-62.

20 Lihat dalam I Gede Pantja Astawa, 2000, Hak Angket Dalam Sistem Ketatanegaraan Indonesia Menurut Undang Undang Dasar 1945, Disertasi, Bandung UNPAD, hlm. 77. 
suatu pemerintahan dalam perspektif demokrasi dapat dilihat sampai seberapa besar partisipasi rakyat dalam pemerintahan. Tingginya partisipasi politik menunjukan bahwa rakyat mengikuti dan memahami masalah politik dan ingin melibatkan diri dalam kegitan itu. Jadi partisipasi politik merupakan pengejawantahan kekuasaan politik yang absah. Dalam kaitan ini, konsep keterwakilan menunjukan hubungan antara orang-orang, yakni pihak yang mewakili dan diwakili, dimana orang yang mewakili mempunyai sederet kewenangan sesuai dengan kesepakatan antar keduanya. Perwakilan merupakan suatu konsep bahwa seseorang atau suatu kelompok mempunyai kemampuan atau kewajiban untuk berbicara atau bertindak atas nama suatu kelompok yang lebih besar. Perwakilan ini disebut perwakilan politik. Perwakilan politik menggambarkan hubungan perwakilan (yang tersusun dalam lembaga atau badan perwakilan) di mana si wakil bertindak sebagai wakil rakyat yang diwakilinya.

Robert Dahl, dalam kaitan ini mengemukakan tujuh kriteria demokrasi untuk mengamati ada tidaknya demokrasi yang diwujudkan dalam suatu pemerintahan negara. Pertama, Control over government decicions about policy is constitusionally vested in elected officials; kedua, Elected officials are chosen and peacfully removed in relatively frequent, fair and free elections in which coercion is quite limited; ketiga, Practically all adults have the right in vote in these elections; keempat, Most adults have the rigth to run for public officer for which candidates run in these elections; kelima, Citizens have an effectifly enforced right to freedom of expression, particulary political expression, including criticsm of of the officials, the conduct of the government, the prevalling political, economic, and social system, and the dominants idiology; keenam, These olso have acces of alternative sources of information that are not monopolized by the government or any other single group; dan ketujuh, Finally the have and effectively enforced right to form and join autonomous associations, including political parties interest groups, that attempt to influnce the government by competing in elections and by other peaceful means. (Pada akhirnya mereka mempunyai hakhak yang diperjuangkan secara efektif untuk membentuk dan bergabung pada sosiasi otonom, termasuk kelompok kpentingan partai politik, yang mencoba mempengaruhi pemerintah dengan berkompetisi dalam pemilihan dan melakui sarana-sarana damai lainnya). ${ }^{21}$

Kriteria ideal yang disampaikan oleh Robert Dahl tidak selaras dengan pengaturan negara terhadap pembatasan hak anggota TNI dan Polri dalam proses politik, karena tidak diberikannya akses perwakilan di lembaga legislatif dan tidak diberikan hak untuk dipilih dalam Pemilihan Umum. Hal ini mengindikasikan bahwa tidak terdapatnya sinkronisasi hukum antara pembatasan hak pilih bagi TNI dan Polri dengan konsepsi Hak Asasi Manusia dalam konteks masyarakat demokratis di Indonesia.

Konsep hak (right) dengan ajektif manusia (human) mempunyai implikasi instrinsik bahwa hak-hak itu dimiliki oleh laki-laki mau pun perempuan (men and women) secara sama. Seluruh manusia dimanapun dan kapanpun karena kemanusiaannya (humanity) tanpa memandang jenis kelamin, ras, usia, kelas sosial, kewarganegaraan, etnis atau afiliasi kesukuan, kekayaan, jabatan, keahlian, agama, ideologi, dan komitmen-komitmen lainnya. Dengan keseluruhan pemikiran di atas, maka tepat yang dikatakan oleh Todung Mulya Lubis, bahwa menelaah HAM sesungguhnya adalah menelaah totalitas kehidupan, sejauh mana kehidupan kita memberi tempat yang wajar kepada kemanusiaan. ${ }^{22}$ Hal inilah yang kemudian mengantar pada eksistensi hukum dalam negara yang seharusnya memberikan tempat dan hak politik bagi anggota TNI dan Polri ke dalam kategori inalienable, tidak dapat dialihkan, dirampas, atau diganggu gugat; dan impre-

21 Afan Gaffar, 2000, Politik Indonesia: Transisi Menuju Demokrasi, Yogyakarta: Pustaka Pelajar, hlm. 6-7.

22 Todung Mulya Lubis, "Menegakan Hak Asasi Manusia, Menggugat Diskriminasi", Jurnal Hukum dan Pembangunan, Vol. 39 No. 1, J anuari-Maret 2009, J akarta: Fakultas Hukum Universitas Indonesia, hlm. 61. 
scriptible, tidak dapat hilang, betapapun telah digerogoti atau gagal dalam pemenuhannya.

Perlu dicermati bahwa keberadaan dari HAM memberikan kewajiban kepada negara, yakni kewajiban untuk menghormati (to respect), kewajiban untuk melindungi (to protect), dan kewajiban untuk memenuhi (to fulfil) HAM. Jika suatu negara gagal dalam memenuhi satu dari kewajiban itu maka suatu negara bisa dikatakan telah melanggar HAM. Kewajiban untuk menghormati HAM mensyaratkan negara untuk mencegah atau menahan dari melanggar atau mengurangi penikmatan hak asasi warga. Kewajiban untuk melindungi mensyaratkan negara untuk melindungi warga dari pelanggaran hak asasi oleh pihak ketiga. Sedangkan kewajiban untuk memenuhi HAM mensyaratkan negara untuk mengambil langkahlangkah legislasi, administrasi, keuangan, peradilan dan upaya-upaya lain untuk mewujudkan hak tersebut. Dengan demikian, hak politik WNI yang kebetulan jadi anggota TNI dan Polri tidak dapat dihapuskan oleh siapapun, kecuali jika mereka tak bersedia menggunakannya. Problematika dalam meletakkan supremasi hukum sebagai landasan utama berdemokrasi dan upaya penegakan keadilan tidak semata-mata terletak pada halangan struktural atas lemahnya political will penegak hukum dalam penegakan prinsip justice for all, tetapi juga pada sangat mudahnya norma hukum tidak saja belum terisi oleh nilai-nilai keadilan, tetapi hukum juga sering kali mengabdikan diri sebagai instrumen kekuasaan. ${ }^{23}$ Perlu ditegaskan bahwa hak pilih anggota TNI dan Polri pernah dilaksanakan pada Pemilu 1955 tanpa menimbulkan polarisasi atau gangguan keamanan sebagaimana dikhawatirkan sementara kalangan dewasa ini.

\section{Penutup \\ Simpulan}

Pengaturan tentang hak pilih bagi anggota TNI dan Polri dalam tiga periode terakhir

23 Marcus Priyo Gunarto, "Perlindungan Hak Asasi Manusia Dalam Dinamika Global", J urnal Mimbar Hukum, Vol. 19 No. 2, J uni 2007, Fakultas Hukum Universitas Gadjah Mada, hlm. 259 mengalami kemunduran. Hal ini dikarenakan pada masa Orde Lama, angkatan bersenjata dan polisi diberikan hak memilih sebagaimana termaktub dalam Undang-Undang No. 7 Tahun 1953 tentang Pemilihan Anggota Konstituante dan Anggota Dewan Perwakilan Rakyat. Pada Orde Baru, ABRI tidak diberikan hak untuk memilih, namun keberadaan ABRI dalam ranah ranah politik diatur secara khusus melalui mekanisme pengangkatan dalam lembaga legislatif dan diatur dalam Undang-Undang No. 15 tahun 1969 tentang Pemilihan Umum AnggotaAnggota Badan Permusyawaratan/Perwakilan Rakyat. Pada era reformasi, hak pilih dan memilih bagi anggota TNI dan Polri dihilangkan sebagaimana diamanatkan oleh Tap MPR No. VII/ 2000 tentang Peran TNI dan Polri, UndangUndang No.2 Tahun 2002 tentang Kepolisian Negara Republik Indonesia dan Undang-Undang No. 34 tahun 2004 tentang Tentara Nasional Indonesia, sehingga TNI dan Polri hanya melaksanakan tugas negara tanpa adanya hak politik yang melekat dalam diri instansi tersebut.

Hak memilih adalah hak yang bersifat personal dan bukan institusional, oleh karena itu negara mempunyai kewajiban untuk menghormati hak asasi manusia dan mencegah atau menahan dari melanggar atau mengurangi penikmatan hak asasi dari warga negaranya. Dengan demikian, hak politik WNI yang menjadi anggota TNI dan Polri tidak dapat dihapuskan oleh siapapun, kecuali jika mereka tak bersedia menggunakannya. Hal ini bermakna bahwa pada era reformasi ini belum terdapatnya sinkronisasi hukum, baik secara vertikal maupun horizontal antara penghapusan hak pilih bagi TNI dan Polri dengan konsepsi Hak Asasi Manusia dalam konteks masyarakat demokratis. Hal ini dikarenakan kriteria partisipasi dan keterwakilan sebagimana termaktub dalam nilainilai ideal demokrasi belumlah terwujud.

\section{Saran}

Perlu adanya perubahan pengaturan terhadap hak pilih TNI dan Polri di Indonesia. Mengacu pada kaidah demokrasi universal, seseorang yang memiliki profesi tertentu tidak kehilangan hak-hak politiknya, khususnya hak 
memilih dalam pemilu. Semua warga negara pada prinsipnya mempunyai hak dan kewajiban sama.

Upaya-upaya preventif yang dapat dilakukan pemerintah dalam rangka pemulihan hak pilih bagi anggota TNI dan Polri dapat berupa Pertama, menumbuhkan sikap profesional pada anggota TNI dan Polri dalam menjalankan tugasnya.. Selain itu, anggota TNI dan Polri harus merespon perkembangan eksternal, guna di jadikan pertimbangan dalam menjalankan reformasi internalnya. Kedua, memperbaiki kesejahteraan anggotanya utamanya yang berpangkat rendah. Kesejahteraan dapat menghindarkan anggota TNI dan Polri dari kemungkinan pemanfaatan jasa mereka oleh pihak tertentu untuk meraih kepentingan pribadi atau golongannya dalam bidang politik, khususnya pada saat pemilu. Peningkatan kesejahteraan ini salah satunya dapat dilakukan dengan cara mengurangi perekrutan anggota TNI dan Polri karena dalam perkembangan dunia pertahanan keamanan, jumlah anggota militer tak lagi menjadi penentu utama, tetapi tergantikan oleh teknologi. Dengan pengurangan rekrutmen anggota TNI dan Polri, maka anggaran yang tidak terpakai dapat dialihkan pengalokasiannya untuk teknologi pertahanan keamanan serta untuk meningkatkan kesejahteraan anggotanya.

\section{Daftar Pustaka}

Armiwulan, Hesti. "Hak Asasi Manusia dan Hukum". Jurnal Yustika. Vol. 7 No. 2. Desember 2004. Surabaya: Fakultas Hukum Universitas Surabaya;

Astawa, I Gede Pantja. 2000. Hak Angket DaIam Sistem Ketatanegaraan Indonesia Menurut Undang Undang Dasar 1945. Disertasi. Bandung: UNPAD;

Departemen Pertahanan dan Keamanan, 24 J uni 2010, Hak Pilih TNI, Bagai Pedang Bermata Dua, dapat diakses dalam http:// www. dephan.go.id/ modules. php? name $=$ News\&file $=$-article $\&$ sid $=7514$;

Gaffar, Afan. 2000. Politik Indonesia: Transisi Menuju Demokrasi. Yogyakarta: Pustaka Pelajar;
Gunarto, Marcus Priyo. "Perlindungan Hak Asasi Manusia Dalam Dinamika Global". J urnal Mimbar Hukum Vol. 19 No. 2. Juni 2007. Yogyakarta: Fakultas Hukum Universitas Gadjah Mada;

Hasan, M. Nur. "Tantangan Demokrasi di Indonesia", Jurnal Aspirasi. Vol. 16 No. 1. Juli 2006. Jakarta: Magister IImu Hukum Trisakti;

Hasibuan, Albert "Politik Hak Asasi Manusia (HAM) Dan UUD 1945", Law Review. Vol. 8 No. 1. Juli 2008. Jakarta: Fakultas Hukum Universitas Pelita Harapan;

Hasnati. "Pertautan Kekuasaan Politik dan Negara Hukum". J urnal Hukum Respublica. Vol. 3 No. 1. Tahun 2003. Pekanbaru: Fakultas Hukum Universitas Lancang Kuning;

J ulia, Syamsiar. "Pelanggaran HAM dan Peranan Polri Dalam Penegakan Hukum di Indonesia". Jurnal Equality. Vol. 11 No. 2. Agustus 2006. Medan: Fakultas Hukum Universitas Sumatera Utara;

Lubis, Todung Mulya. "Menegakan Hak Asasi Manusia, Menggugat Diskriminasi". J urnal hukum dan Pembangunan. Vol. 39 No. 1. J anuari-Maret 2009. J akarta: Fakultas Hukum Universitas Indonesia;

Nurhasan. "Pasang Surut Penegaka; n HAM dan Demokrasi di Indonesia". Jurnal IImu Hukum Litigasi. Vol. 6 No. 2. J uni 2005. Bandung: Fakultas Hukum Universitas Pasundan;

Prihatono, T. Hari. 2008. "Departemen Pertahanan-TNI-Masyarakat Sipil: Relasi dalam Formulasi Kebijakan dan Transparansi Implementasi," dalam diskusi untuk simposium "10 Tahun Reformasi Sektor Keamanan di Indonesia" dengan tema "Reformasi TNI dan Departemen Pertahanan RI Pasca Orde Baru di Indonesia", yang diselenggarakan atas kerja sama Lesperssi-HRWG-IDSPS-DCAF, Hotel Sultan, J akarta 28-29 Mei 2008;

Sudrajat, Tedi "Problematika Penegakan Hukuman Disiplin Kepegawaian", Jurnal Dinamika Hukum. Vol. 8 No. 3. September 2008. Purwokerto: Fakultas Hukum Universitas J enderal Soedirman;

Sumali. “Urgensi TNI di Bingkai Konstitusi Dalam Perspektif Yuridis Politis". Jurnal Hukum Respublica. Vol. 3 No. 1. Tahun 2003. Pekanbaru: Fakultas Hukum Universitas Lancang Kuning. 